\title{
IMPACTS OF PRICE FLUCTUATION ON RESOURCE ALLOCATION EFFICIENCY
}

\author{
Congming Ding* $\quad$ Yanling $\mathrm{Xi}^{\dagger} \quad$ Zhongchang Chen ${ }^{\ddagger}$ \\ Keywords: Price fluctuation, Allocation efficiency, Threshold effect, Stochastic \\ frontier analysis \\ JEL: C33, D61, E32
}

\begin{abstract}
This paper develops a dynamic model to analyze the effects of different levels of price fluctuations on resource allocation efficiency. The model shows two different strategies that enterprises adopt when they confront different levels of price fluctuations. In respond to small fluctuations, enterprises might adopt a conservative strategy of maintaining the ratio of factor inputs and leaving production plans unchanged of the adjustment cost. As a result, allocation inefficiency is unavoidable. However, greater fluctuations which increase the opportunity cost of a conservative strategy
\end{abstract}

*Department of Economics, Faculty of Public Adminstration, Chongqing University, 174 Shazheng Road, Shapingba District, Chongqing 400044, P. R. China, Email: hayekting@126.com

†Department of Economics, Faculty of Public Adminstration, Chongqing University, 174 Shazheng Road, Shapingba District, Chongqing 400044, P. R. China, Email: yanling.xi@hotmail.com

$\ddagger$ Department of Economics, Faculty of Public Adminstration, Chongqing University, 174 Shazheng Road, Shapingba District, Chongqing 400044, P. R. China, Email: czcmx@cqu.edu.cn 
induce enterprises to accept an adjustment strategy; they must change the ratio of factor inputs and the production plans passively. This transformation indicates that a threshold effect exists in the price fluctuations' influence on resource allocation inefficiency. Using stochastic frontier analysis (SFA) and China's provincial panel data of 1978 to 2007, this paper confirms that price fluctuation has a nonlinear effect on allocation efficiency loss, and concludes that traditional analyses underestimate the adverse impacts of price fluctuation on China's economy.

\section{INTRODUCTION}

In recent decades, macroeconomists have tended to study the sources of fluctuations and the determinants of growth separately. They have concluded that fluctuations are mainly affected by lack of short-term effective demand, monetary shocks and exogenous cost shocks, while growth is impacted by capital investments, technical progress and institutional changes. A dichotomy between short- and long-term periods has resulted in different research paradigms between fluctuations and growth. Since Nelson and Plosser (1982)'s research on non-stationary macroeconomic, and Real Business Cycle Theory by Kydland and Prescott (1982), Long and Plosser (1983), economists have held that macroeconomic time serials cannot be simply separated into unrelated shortterm fluctuation and long-term growth, and that fluctuations and growth can exist in a general equilibrium. In reality, more attention has been paid to the reintegration of fluctuation and growth.

Using the panel data for 92 countries from the period 1950-1985, Ramey and Ramey (1995) prove a negative correlation between short-term fluctuation and long-term growth. However, they also find no evidence of any relationship between investment and fluctuation. This conclusion has an important implication for policy: stable economic policies have not only tiny welfare effects (Lucas, 1987), but also significant long-term influence. Ramey and Ramey's study prompts us to consider how, instead of influencing capital investment, fluctuations negatively affect growth, as is confirmed by empirical studies. 
Existing studies show three classes of transmission mechanism through which growth and fluctuations might relate. One class emphasizes the influences of fluctuations on factor inputs. The other two classes emphasize the impacts of structural factors of an economy and of total factor productivity (TFP), respectively. As discussed below, these three types of mechanism can explain, to some extent, the relationship between price fluctuations and growth.

The first class of transmission mechanism by which fluctuations influence growth, via factor inputs, is ambiguous both in theoretical and empirical studies. On the one hand, residents and enterprises increase investments out of precautionary motivation when they confront price fluctuations which, in turn, may raise the social savings rate and the investment rate. In addition, residents may increase human capital investment to avoid uncertainty about future income (Canton, 2002). On the other, investment irreversibility may cause negative correlation between fluctuation (uncertainty) and investment (Pindyck, 1991).

The second class estimates the structural factors that influence the relationship between fluctuations and growth. Hnatkovska and Loayza (2003) believe that the existence of structural factors leads to a nonlinear relationship between fluctuations and growth. That is, the less complete a country's financial system, and the lower its income level, the more severe the negative effects of fluctuations on growth. Kose, et al. (2006) emphasize the impact of foreign trade and financial liberalization on the fluctuation-growth relationship. Fatás and Mihov (2006) emphasize the negative effect of fiscal policy fluctuations on growth. However, both of the studies by Hnatkovska and Loayza (2003) and Kose, et al (2006) discuss little of the channels through which structural factors affect growth.

The third class focuses on the effects of TFP on growth. Rafferty (2004) confirms using empirical methods that the negative relationship between fluctuations and growth can be explained, to some degree, by the impact of price fluctuations on TFP. Moreover, TFP growth includes not only technological progress, but also changes in allocation efficiency caused by resource reallocation (Farrell, 1957; Aigner \& Chu, 1968). As yet, studies mostly focus on technological progress. For example, Aghion, et al. (2005) analyze the impacts of price fluctuations 
on research and development (R \& D) and growth under the framework of endogenous growth. In an imperfect financial market, investment in R \& D, with a long payback period, appears a pro-cyclical fluctuation and a lower average growth. Ahmet Faruk (2007) further emphasizes that since R \& D requires capital intensive investment, price fluctuation may lead to a lack of $\mathrm{R} \& \mathrm{D}$ investment, and a decline in technological progress in an imperfect financial market. However, it has not yet been confirmed whether or not price fluctuations affect allocation efficiency, or by what mechanism the effect is achieved.

The objective of this paper is to pose further conclusions about how price fluctuations affect growth. Compared to existing studies, this paper proposes two main innovations. Whereas most-tend to emphasize the empirical relationship between fluctuation and growth, and attend mainly to factor inputs and technological progress, this paper focuses on the theoretical and empirical relationship between price fluctuations and allocation efficiency. Second, in order to avoid the omission bias caused by two-step decomposition, this paper uses SFA with maximum likelihood estimation (Wang 2002a) to evaluate the influence of price fluctuations on allocation efficiency directly.

The structure of this paper is as follows. The following section lays out the dynamic model describing how price fluctuation influences resource allocation efficiency. Section 3 contains the description of our methodology and data. Section 4 presents our econometric test results, and section 5 serves as the conclusion.

\section{THEORY}

Different levels of price fluctuation cause different levels of efficiency loss. Furthermore, as price fluctuation increases, the efficiency loss of whole society increases not in a linear trend, but in a parabolic trend in which a critical value exists.

To prove our theory, it is important to evaluate how a micro-enterprise reacts to different levels of price fluctuations. Using as reference the new Keynesian theory of incomplete market and the non-ignorable menu cost (Mankiw, 1991; 
Romer, 1996), we determine that changes in relative price disrupt the factor allocation equilibrium of an enterprise, and the adjustment cost does exist when the production plan or factor proportion is adjusted. As a result, decision-makers don't respond in a timely and sensitive manner to slight price changes. For example, in the case of labor employment, dismissing staffs may induce labor disputes or disclosures of business information, as well as costs for re-recruitment or re-training, so an enterprise might rationally maintain the output and the factor input ratios even though the exogenous price has changed. Moreover, an increase in capital investment may also be delayed or even banned due to the irreversibility of capital adjustment. Therefore, if price fluctuation is relatively minor, near-rational decision-makers will choose to inertly maintain the current production plan and factor input density. However, if the price fluctuation is relatively large, decision-makers should choose to re-arrange production plans, and as a result, the benefit of adjustment may far outweigh the cost. In all, the maintenance strategy in response to a minor price fluctuation and the adjustment strategy in response to a substantial price fluctuation have important implications for the study of an enterprise's resource allocation efficiency.

Given the framework of the above-discussed strategies, we study the output adjustment behavior of an enterprise for which price is an exogenous and fixed factor. Given a random price $P$, the enterprise determines its own output $Q$, hence the supply curve is $P=a+b \cdot Q$, where $a>0, b>0$. Given price $P_{0}$, and the supply of the enterprise is $Q_{0}=\left(P_{0}-a\right) / b$.

Assume one-time adjustment cost $F_{i}$ of the $i$ th enterprise, and normalize the number of enterprise, so $i \in(0,1)$. If the return on adjustment is greater than $F_{i}$, the enterprise adjusts its output to an optimal one. Otherwise, the inert enterprise prefers to keep the output unchanged.

The enterprise's net profit $\pi=P Q-C(Q)$, where $C(Q)$ denotes the production cost. If price changes from $P_{0}$ to $P_{1}$, and the enterprise adjusts output to $Q_{1}$, then profit

$$
\pi_{1}=P_{1} \frac{P_{1}-a}{b}-\int_{0}^{\frac{P 1-a}{b}}(a+b Q) d Q
$$


where $P_{1} \frac{P_{1}-a}{b}$ denotes the gross earning given price $\mathrm{P}_{1}$, and $\int_{0}^{\frac{P 1-a}{b}}(a+b Q) d Q$ stands for the total cost when output $Q_{1}=\left(P_{1}-a\right) / b$. If the enterprise keeps its output $Q_{0}=\left(P_{0}-a\right) / b$ unchanged, then profit under a changed price

$$
\pi_{0}=P_{1} \frac{P_{0}-a}{b}-\int_{0}^{\frac{P_{0}-a}{b}}(a+b Q) d Q
$$

Suppose the net income of the output adjustment is $\Delta \pi=\pi_{1}-\pi_{0}$, and price change $\Delta P=P_{1}-P_{0}$, so $\Delta \pi=\Delta P^{2} / 2 b$ is obtained after simple calculations. As long as $\Delta \pi$ is less than $F_{i}$, the enterprise will maintain the output level $Q_{0}$. Otherwise, the enterprise will adjust it to $Q_{1}$.

The $i$ th enterprise will suffer an efficiency loss $L_{i}=\Delta P^{2} / 2 b$ if it doesn't adjust output. Instead, the efficiency loss is equal to the one-time adjustment $\operatorname{cost} L i=F i=f \cdot i$. We obtain the allocation efficiency loss of the $i$ th enterprise as follows:

$$
L_{i}=\left\{\begin{aligned}
\Delta P^{2} / 2 b, & \text { if } \Delta P^{2} / 2 b<F_{i} \\
F_{i}, & \text { if } \Delta P^{2} / 2 b \geq F_{i} ; ;
\end{aligned}\right.
$$

Assume the existence of heterogeneous adjustment cost, and adjustment cost $F_{i}$ obeys the uniform distribution $F_{i} \sim U(0, f)$. Reorder the enterprises in accordance with adjustment costs from low to high, and the adjustment cost of the $i$ th enterprise goes to $F_{i}=f \cdot i$.

When $\Delta P^{2} / 2 b=f$, all enterprises adjust their production plans. Each enterprise's efficiency loss obeys $F \sim U(0, f)$, and entire loss suffered by the economy is $L=f / 2$;

When $0=\Delta P^{2} / 2 b<f$, the adjustment cost of the $\Delta P^{2} / 2 b f$ th enterprise is $\Delta P^{2} / 2 b$. Given price change $\Delta P$, the first $\Delta P^{2} / 2 b f$ enterprises will adjust their outputs because their adjustment costs are lower than the critical value $\Delta P^{2} / 2 b$. As a result, each enterprise's efficiency loss is $F_{i} \sim U\left(0, \Delta P^{2} /\right.$ $2 b)$; the other $\left(1-\Delta P^{2} / 2 b f\right)$ enterprises which have higher adjustment costs maintain original outputs, so each enterprise suffers efficiency loss $L_{i}=\Delta P^{2} /$ 2b. Finally, the entire economy's overall allocation efficiency loss 


$$
L=\left\{\begin{array}{lr}
\frac{f}{2}, & \text { when } \frac{\Delta P^{2}}{2 b} \geq f ; \\
\frac{\Delta P^{2}}{2 b f} \frac{\Delta P^{2}}{4 b}+\frac{\Delta P^{2}}{2 b}\left(1-\frac{\Delta P^{2}}{2 b f}\right)=\frac{\Delta P^{2}}{2 b}-\frac{\Delta P^{4}}{8 b^{2} f}, & \text { when } 0 \leq \frac{\Delta P^{2}}{2 b}<f
\end{array}\right.
$$

From (4), we find that when price fluctuation increases, efficiency loss shows a decreasing nonlinear trend. The efficiency loss shows a parabolic increasing trend where price fluctuation $\Delta P^{2}=2 b f$, However, when price fluctuation $\Delta P$ ${ }^{2}>2 b f$, efficiency loss reaches a critical value $f / 2$, and then it shows a horizontal trend, as shown in figure 1:

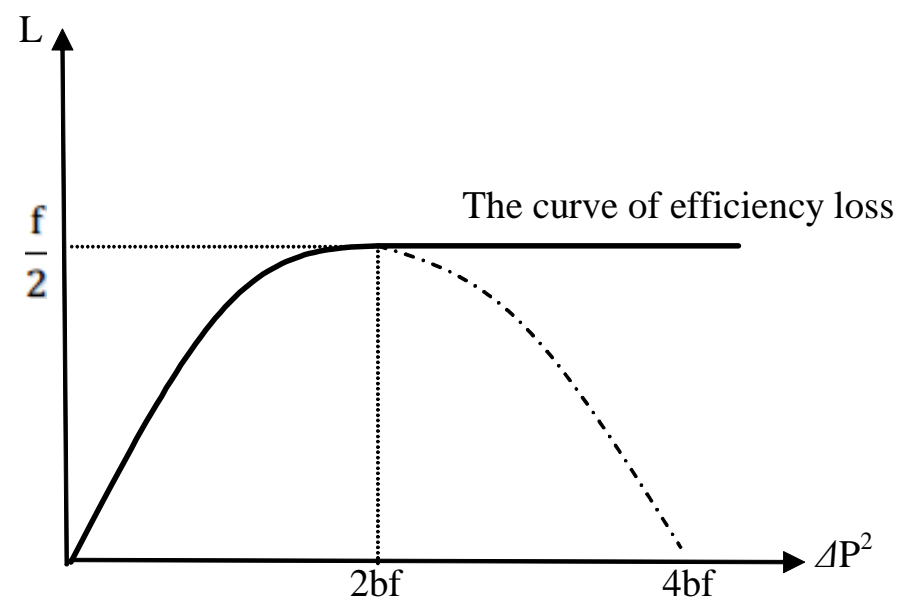

Source: Authors calculation

FIGURE 1-The Curve of Efficiency Loss

In figure 1, although price fluctuation increases allocation efficiency loss on average, the impacts of different levels of price fluctuations on efficiency loss are varied. Lower price fluctuations increase allocation efficiency loss, but the marginal efficiency loss coupled with the increase of price fluctuation shows a decreasing trend, which results mainly from the adjustment ability of enterprises. The opportunity cost of a conservative strategy rises with the increase in price fluctuation, and once the opportunity cost exceeds enterprises' one-time 
adjustment cost, some enterprises will re-combine their factors to avoid the opportunity cost. Therefore, allocation efficiency loss does not increase in a linear trend, but in a parabolic trend. The position that price fluctuations can increase efficiency loss without limit actually neglects to account for the ability of enterprises to actively adjust. Once the fluctuation exceeds the adjustment cost of each enterprise, all enterprises will pay the one-time adjustment cost, and the efficiency loss reaches the critical value of $f / 2$.

\section{METHODOLOGY AND DATA}

\subsection{Methodology}

In order to capture the impact of price fluctuations on allocation efficiency, this paper uses SFA with allocation efficiency equations. In the standard growth accounting, TFP reflects the impact of factors (besides capital and labor) on growth, including the inability of producers to produce on the production possibility frontier due to the exogenous environment and policy variables (Farrell, 1957). Along these lines, Aigner and Chu (1968) delineate TFP into technological progress and resource allocation efficiency (or technical efficiency). Since resource allocation efficiency may be influenced by a variety of random factors or other exogenous policy factors, SFA with allocation efficiency equations can best capture the impact on allocation efficiency.

There are two categories of random allocation efficiency modeling in empirical research. One is represented by Kumbhakar, et al. (1991), Huang and Liu (1994), Battese and Coelli (1995), whom estimate the mean model of exogenous technical inefficiency term $u$ (KGMHLBC). The other, used by Caudill \& Ford (1993), Caudill, et al (1995) and Hadri (1999) solve the problem of heteroscedasticity of the random inefficiency term by modeling the allocation efficiency variance $\sigma_{v}^{2}$ (CFCFGH). Wang (Wang, 2002a, 2002b) integrates the above two models, and models both the mean and variance of allocation efficiency loss using maximum likelihood estimation. The estimated equations of 
this model are as follows:

$$
\begin{gathered}
\ln y_{i t}=\ln y_{i t}{ }^{*}-u_{i t} \\
\ln y_{i t}{ }^{*}=X \prime_{i t} \beta+v_{i t} \\
X \prime_{i t} \beta=\beta_{0}+\Sigma_{k} \beta_{k} \ln x_{k i t}+\frac{1}{2} \Sigma_{k} \Sigma_{l} \beta_{k l} \ln x_{l i t} \ln x_{k}
\end{gathered}
$$

Allocation efficiency loss equations are as follows:

$$
\begin{gathered}
u_{i t} h\left(z_{i t}, \delta\right) \cdot N^{+}\left(\tau, \sigma^{2}\right) \\
h\left(z_{i t}, \delta\right)=\delta_{0} \frac{\exp \left(\Delta P^{2}\right)}{1+\exp \left(\Delta P^{2}\right)}+\delta_{1} \text { open }+\delta_{2} h u m a n+\delta_{3} \text { fegdp } \\
v_{i t} N\left(0, \sigma_{v}^{2}\right)
\end{gathered}
$$

Equation (5) reflects the deviation of potential output $\ln y_{i t}{ }^{*}$ from real output $\ln y_{i t}$ caused by allocation efficiency loss $u_{i t}$. (6) illustrates that potential output $\ln y_{i t}{ }^{*}$ is influenced by a number of factor input elements $\mathrm{X}$ and random imponderable $v_{i t}$. Assume that composite residual term $u_{i t}$ and $v_{i t}$ are independent, as are irrelative to explaining variables of the regression. Composite residual variance $\sigma^{2}=\sigma_{v}^{2}+\sigma_{u}^{2}$. Define $\gamma=\sigma_{u}^{2} / \sigma_{v}^{2} \in[0,1]$, and if $\gamma=0$, the deviation from potential output is mainly caused by $v_{i t}$. Otherwise, if $\gamma$ is close to 1 , it is mainly caused by allocation inefficiency. (7) is the second order Taylor series approximation of the transcendental logarithmic production function (translog production function). (8) shows that technical inefficiency term is non-negative, so Tobit regression is adopted. Allocation efficiency loss $u_{i t}$ is impacted by the exogenous environment and policy variable $z_{i t}$. Furthermore, Wang \& Gong (2006) point out that variables impacting China's regional allocation efficiency include: human capital level, openness level and proportion of public expenditure. In order to study the threshold effect of the price fluctuation on allocation efficiency, this paper further controls the price fluctuation $\Delta P^{2}$ besides the three variables above. (9) presents a logistic transformation of the price fluctuation. The first derivative of the price fluctuation $\Delta P^{2}$ on allocation efficiency loss $u_{i t}$ is 
greater than zero, the second derivative is less than zero, and the limits of the first and second derivative are both $0^{1}$. This indicates that the price fluctuation increases allocation inefficiency, but such increase is not infinite; instead, there is a threshold equaling $\delta_{0} N\left(\tau, \sigma^{2}\right)$. (10) shows the distribution of regression error $v_{i t}$. In (6) - (11), maximum likelihood estimation is utilized in order to obtain unbiased and consistent estimates.

Equations (5) - (10) have three advantages in model-setting and estimation. Firstly, both the mean and the variance of allocation efficiency loss are modeled using the one-step maximum likelihood estimation. Compared with the two-step regression method which has bias because it first estimates efficiency loss term $u_{i t}$, and then obtains parameter estimate $\delta$, the one-step maximum likelihood estimation both avoids the bias, and improves the estimation efficiency in the KGMHLBC and CFCFGH by regressing $u_{i t}$ and policy variable $z_{i t}{ }^{2}$.Secondly, translog production function utilized in this paper can be seen as a rational second order approximation of the unknown production function, and is widely used in empirical studies because of its advantages, such as: variable elasticity of substitution, unknown production function, non-neutral technical progress and nonlinear effects of factor inputs, etc (Christensen, et al., 1973; Kim \& Young, 1992). Thirdly, by logistically transforming price fluctuation, nonlinear effects of price fluctuations on efficiency loss can be well captured.

\footnotetext{
${ }^{1}$ In complete curve $\mathrm{y}=\operatorname{logistic}(\mathrm{x})$, if $\mathrm{x}<0$, then $\mathrm{dy} / \mathrm{dx}>0$, d2y $/ \mathrm{dx} 2>0$; if $\mathrm{x} \geq 0$

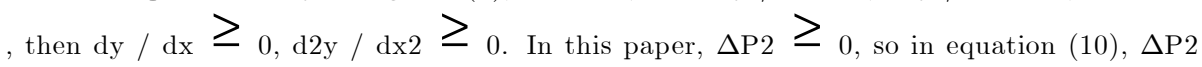
increases the resource allocation efficiency loss, to the limit of $0 \mathrm{~N}(, 2)$.

${ }^{2}$ Problems existing in two-step estimation are as follows: allocation efficiency loss uit is assumed to be affected by external variable zit in the estimation of allocation efficiency equation. However, in order to avoid bias of uit obtained in the first step estimation, uit is assumed to be unaffected by other variables, or input variable xit is irrelevant to the relative variables in production function equation yit. Obviously, the assumptions of uit are contradictory in two-step estimation above (Wang, Gong, 2006).
} 


\subsection{Data description}

Research data of this paper are mainly from "Comprehensive Statistical Data and Materials on 50 years of New China" [1999] and "China Statistical Yearbook". Full samples are from 30 cities, provinces and autonomous regions of China of the period 1985-2007, combining data of Chongqing province with those of Sichuan province. Detailed descriptions of variables are as follows:

1. Real GDP. We use 1978 as the base year; we calculate real GDP mainly based on GDP growth index.

2. Price fluctuation index. $\Delta P$ is the inflation rate, so $\Delta P^{2}$ is the square of inflation rate. Three indicators are used in measuring the inflation rate: consumer price index (CPI), price index of investment goods (PPI) and GDP deflator (DPI). GDP deflator is equal to nominal GDPto-real GDP ratio, and is in a form of chain price index ${ }^{3}$.

3. Capital stock level. We use estimated data by Shan (2008) for reference and adjust the base year to 1978 by using price index of fixed asset, so the latest economic census data after annual revisions is used. See details of data in Shan (2008).

4. Employment level. We use the sum of labor of each Chinese province, so the quality of labors cannot be measured. To solve this problem, an index of human capital level is constructed.

5. Human capital level. The number of students in Chinese colleges is used. In order to eliminate the impacts of China's policies such as policy of enrollment expansion in higher education, and the factor that workers hardly increase labor productivity without a few years of work experience, we use the average amount of college students of the past three years as the approximate value of the human capital level of provinces.

\footnotetext{
${ }^{3}$ The official statistics of China's provincial price index of fixed asset investment start from 1992; we use as reference the approach by Shan(2008), namely, to obtain the weighted price index of fixed assets based on the compositions of fixed assets and the price index of each part of them, to calculate fixed assets price index of $1978-1991$.
} 
6. Degree of openness. The ratio of import and export volumes to GDP is used. Import and export volumes, mostly in dollars, are converted to comparable RMB prices by using the average exchange rate of the same year.

7. Financial expenditure. The ratio of local government budget expenditure to local nominal GDP level is used. A larger proportion of local government expenditure reflects greater governmental intervention in a local economy. Such involvement can improve allocation efficiency by increasing public goods supplies; on the other hand, it may cause market distortions, and hence hinder improvement of allocation efficiency.

\section{ECONOMETRIC RESULTS}

TABLE 1-Estimation Results of Price Fluctuation and Allocation Efficiency Loss (Sample Range: 1978-2007)

\begin{tabular}{|c|c|c|c|c|c|c|}
\hline \multirow{2}{*}{$\begin{array}{c}\text { Estimation } \\
\text { of Stochastic } \\
\text { Frontier } \\
\text { Production } \\
\text { Function }\end{array}$} & \multicolumn{2}{|c|}{ Consumer Price } & \multicolumn{2}{|c|}{ Investment Goods Price } & \multicolumn{2}{|c|}{ Deflator } \\
\hline & I & II & III & IV & V & VI \\
\hline Capital & $\begin{array}{c}0.6312 * * * \\
(6.38)\end{array}$ & $\begin{array}{c}0.5956 * * * \\
(5.97)\end{array}$ & $\begin{array}{c}0.4201 * * * \\
(4.46)\end{array}$ & $\begin{array}{c}0.4079 * * * \\
(4.33)\end{array}$ & $\begin{array}{c}0.4292 * * * \\
(4.57)\end{array}$ & $\begin{array}{c}0.4681 * * * \\
(5.01)\end{array}$ \\
\hline Labor & $\begin{array}{c}0.6815 * * * \\
(3.69)\end{array}$ & $\begin{array}{c}0.7025 * * * \\
(3.82)\end{array}$ & $\begin{array}{c}0.7404 * * * \\
(4.42)\end{array}$ & $\begin{array}{c}0.7568 * * * \\
(4.54)\end{array}$ & $\begin{array}{c}0.7401 * * * \\
(4.43)\end{array}$ & $\begin{array}{c}0.7505 * * * \\
(4.55)\end{array}$ \\
\hline Capital Labor & $\begin{array}{c}-0.0596 * * * \\
(-4.44)\end{array}$ & $\begin{array}{c}-0.0572 * * * \\
(-4.28)\end{array}$ & $\begin{array}{c}-0.0498 * * * \\
(-3.85)\end{array}$ & $\begin{array}{c}-0.0481 * * * \\
(-3.72)\end{array}$ & $\begin{array}{c}-0.0508 * * * \\
(-3.94)\end{array}$ & $\begin{array}{c}-0.0547 * * * \\
(-4.30)\end{array}$ \\
\hline $\begin{array}{l}\text { Square of } \\
\text { Capital }\end{array}$ & $\begin{array}{c}0.0412 * * * \\
(21.65)\end{array}$ & $\begin{array}{c}0.0416 * * * \\
(22.01)\end{array}$ & $\begin{array}{c}0.0422 * * * \\
(22.78)\end{array}$ & $\begin{array}{c}0.0422 * * * \\
(22.84)\end{array}$ & $\begin{array}{c}0.0420 * * * \\
(22.67)\end{array}$ & $\begin{array}{c}0.0415 * * * \\
(22.63)\end{array}$ \\
\hline $\begin{array}{l}\text { Square of } \\
\text { Labor }\end{array}$ & $\begin{array}{c}0.0006 \\
(0.04)\end{array}$ & $\begin{array}{c}-0.00085 \\
(-0.05)\end{array}$ & $\begin{array}{c}0.0035 \\
(0.22)\end{array}$ & $\begin{array}{c}0.0019 \\
(0.12)\end{array}$ & $\begin{array}{r}0.0032 \\
(0.21)\end{array}$ & $\begin{array}{c}0.0024 \\
(0.16)\end{array}$ \\
\hline Capital Time & $\begin{array}{c}-0.0081 * * * \\
(-5.49)\end{array}$ & $\begin{array}{c}-0.0075 * * * \\
(-5.02)\end{array}$ & $\begin{array}{l}-0.0022 \\
(-1.62)\end{array}$ & $\begin{array}{c}-0.0023 * \\
(-1.68)\end{array}$ & $\begin{array}{c}-0.0023 * \\
(-1.68)\end{array}$ & $\begin{array}{c}-0.0029 * * \\
(-2.11)\end{array}$ \\
\hline Labor Time & $\begin{array}{c}0.0070 * * * \\
(3.68)\end{array}$ & $\begin{array}{c}0.0062 * * * \\
(3.22)\end{array}$ & $\begin{array}{c}0.0001 \\
(0.05)\end{array}$ & $\begin{array}{l}-0.0002 \\
(-0.09)\end{array}$ & $\begin{array}{c}0.0005 \\
(0.32)\end{array}$ & $\begin{array}{c}0.0018 \\
(1.04)\end{array}$ \\
\hline Time & $\begin{array}{c}-0.0372 * * * \\
(-2.61)\end{array}$ & $\begin{array}{c}-0.0357 * * \\
(-2.48)\end{array}$ & $\begin{array}{c}0.0201 * \\
(1.71)\end{array}$ & $\begin{array}{c}0.0229 * * \\
(1.93)\end{array}$ & $\begin{array}{c}0.0185 \\
(1.58)\end{array}$ & $\begin{array}{c}0.0109 \\
(0.91)\end{array}$ \\
\hline $\begin{array}{l}\text { Square of } \\
\text { Time }\end{array}$ & $\begin{array}{c}0.0014 * * * \\
(5.91)\end{array}$ & $\begin{array}{c}0.0013 * * * \\
(5.75)\end{array}$ & $\begin{array}{c}-0.0000 \\
(-0.32)\end{array}$ & $\begin{array}{c}-0.0001 \\
(-0.40)\end{array}$ & $\begin{array}{c}-0.0000 \\
(-0.43)\end{array}$ & $\begin{array}{c}0.0000 \\
(0.08)\end{array}$ \\
\hline $\begin{array}{c}\text { Constant } \\
\text { Terms }\end{array}$ & $\begin{array}{c}-1.4022 * * * \\
(-2.84)\end{array}$ & $\begin{array}{c}-1.3537 * * * \\
(-2.75)\end{array}$ & $\begin{array}{c}-1.4322 * * * \\
(-3.27)\end{array}$ & $\begin{array}{c}-1.470 * * * \\
(-3.36)\end{array}$ & $\begin{array}{c}-1.4364 * * * \\
(-3.28)\end{array}$ & $\begin{array}{c}-1.4858 * * * \\
(-3.43)\end{array}$ \\
\hline
\end{tabular}




\section{End of Table 1.}

\begin{tabular}{|c|c|c|c|c|c|c|}
\hline \multirow{2}{*}{$\begin{array}{c}\text { Estimation } \\
\text { of Allocation } \\
\text { Efficiency } \\
\text { Loss } \\
\text { Equations }\end{array}$} & \multicolumn{2}{|c|}{$\begin{array}{l}\text { Consumer Price } \\
\text { Index }\end{array}$} & \multicolumn{2}{|c|}{$\begin{array}{l}\text { Investment Goods Price } \\
\text { Index }\end{array}$} & \multicolumn{2}{|c|}{$\begin{array}{c}\text { GDP } \\
\text { Deflator }\end{array}$} \\
\hline & I & II & III & IV & $\mathrm{V}$ & VI \\
\hline $\begin{array}{c}\text { Logistic } \\
\text { Transformati } \\
\text { on of Price } \\
\text { Fluctuation }\end{array}$ & & $\begin{array}{c}0.5178 * * * \\
(3.51)\end{array}$ & & $\begin{array}{c}0.2471 * * \\
(2.48)\end{array}$ & & $\begin{array}{c}0.5710 * * * \\
(5.06)\end{array}$ \\
\hline $\begin{array}{l}\text { Price } \\
\text { Fluctuation }\end{array}$ & $\begin{array}{c}2.6729 * * \\
(2.16)\end{array}$ & & $\begin{array}{c}0.6754 * \\
(1.86)\end{array}$ & & $\begin{array}{c}4.3608 * * \\
(2.55)\end{array}$ & \\
\hline Openness & $\begin{array}{c}-4.8047 * * * \\
(-7.46)\end{array}$ & $\begin{array}{c}-4.4200 * * * \\
(-7.13)\end{array}$ & $\begin{array}{c}-3.2697 * * * \\
(-6.90)\end{array}$ & $\begin{array}{c}-3.2822 * * * \\
(-6.83)\end{array}$ & $\begin{array}{c}-3.4400 * * * \\
(-7.00)\end{array}$ & $\begin{array}{c}-3.2853 * * * * \\
(-6.83)\end{array}$ \\
\hline $\begin{array}{l}\text { Human } \\
\text { Capital }\end{array}$ & $\begin{array}{c}-0.0424 * * \\
(-2.06)\end{array}$ & $\begin{array}{c}-0.0530 * * \\
(-2.48)\end{array}$ & $\begin{array}{c}-0.2704 * * * \\
(-5.50)\end{array}$ & $\begin{array}{c}-0.2566 * * * \\
(-5.38)\end{array}$ & $\begin{array}{c}-0.2518 * * * \\
(-5.14)\end{array}$ & $\begin{array}{c}-0.2093 * * * \\
(-4.82)\end{array}$ \\
\hline $\begin{array}{l}\text { Financial } \\
\text { Expenditure }\end{array}$ & $\begin{array}{c}0.4376 \text { ** } \\
(2.43)\end{array}$ & $\begin{array}{c}0.5112 * * * \\
(2.84)\end{array}$ & $\begin{array}{l}0.1081 \\
(0.61)\end{array}$ & $\begin{array}{l}0.1164 \\
(0.67)\end{array}$ & $\begin{array}{c}0.1584 \\
(0.90)\end{array}$ & $\begin{array}{c}0.5570 * * * \\
(3.01)\end{array}$ \\
\hline $\begin{array}{l}\text { Likelihood } \\
\text { Ratio }\end{array}$ & 175.35 & 180.33 & 190.59 & 192.36 & 192.11 & 203.88 \\
\hline Sample Size & 733 & 733 & 862 & 862 & 862 & 862 \\
\hline
\end{tabular}

Source: Authors calculation

Notes: 1 . * represent the $10 \%$ significance level, ** represent the $5 \%$ significance level, *** represent the $1 \%$ significance level.

2. Inyit is the explained variable in the production function; $u_{i t}$ is the explained variable in the allocation efficiency loss equation.

3. $t$ statistics are shown in the brackets.

Table 1. presents the results of econometric test of (5) - (10) which uses the method of one-step maximum likelihood estimation (Wang, 2002b) and samples of 1978 to $2007^{4}$. The results contain two parts: Section 1 is the estimation

\footnotetext{
${ }^{4}$ This article uses stata10 for empirical research. Stochastic frontier program of maximum likelihood estimation comes from http:/ / homepage. ntu.edu.tw/ wangh/
} 
of stochastic frontier production function (SFPF). Section 2 is the estimation of allocation efficiency loss equations. A translog production function form is used for SFPF, so main variables include not only capital, labor and time, but also the product of them and their respective squared terms. In the equations of allocation efficiency loss, the main factors used to control efficiency loss are price fluctuation, degree of openness, level of human capital and level of financial expenditure. The same production function is set in models I and VI, and the difference lies in the construction of the price fluctuation index in the equations of allocation efficiency loss. CPI is utilized to measure the price fluctuation index in models I and II, unchanged squared CPI in model I and logistic transformation of CPI in model II respectively. In addition, squared price index of investment goods is utilized in models III and IV, unchanged PPI in model III and logistic transformation of PPI in model IV respectively. As for models $\mathrm{V}$ and VI, squared GDP deflator is used, unchanged deflator in model V and logistic transformation of deflator in model VI respectively.

Analyses according to the regression results shown in TABLE 1 are as follows:

1) Overall, influences of price fluctuations on allocation efficiency loss can be better determined using logistic transformation of price fluctuation. In other words, influences are quite noticeable and the results suggest a nonlinear decreasing correlation between price fluctuations and efficiency loss. In order to compare the indicators of horizontal price fluctuation with indicators of price fluctuation after logistic transformation, we calculate the likelihood ratio (LR) in each regression equation group. The model specification can simply be based on the values of LR, which reflects the significance degree of the whole regression. In detail, LRs respectively equal 175.35 and 180.33 in models I and II, 190.59 and 192.36 in models III and IV, and 192.11 and 203.88 in models V and VI. The results indicate that regression equations after logistic transformation fit better. Moreover, LR illustrates that generally, GDP deflators fit better than price index of investment goods in equations V and VI. Direct comparison of fitting results cannot be made between "consumer price" and "GDP deflator" because they have different sample sizes. However, according to the significance of the single variables, variables are all significant at a $5 \%$ level except the square 
of labor in equation II, compared to equation VI, so the analyses below focus on equation II.

2) Translog production function adequately captures the nonlinear interaction between various factor inputs and output levels. According to the parameter estimation in TABLE 1 and the definition of average capital output elasticity, average capital output elasticity can be expressed as

$$
E_{k}=\partial \ln y / \partial \ln k=0.5956-0.0572 \ln l+0.0832 \ln k-0.0075 t
$$

We assign mean value to each variable, then the value $E_{k}$ of is 0.578 . Average labor output elasticity can be expressed as

$$
E_{L}=\partial \ln y / \partial \ln l=0.7025-0.0572 \ln k+0.0062 t
$$

and the value of $E_{L}$ is $0.448 . E_{k}+E_{L}=1.026$, this result indicates that the production function has constant returns to scale. At the same time, estimates of the translog production function illustrate a trend of differentiation, with economic development, between capital output elasticity $E_{k}$ and labor output elasticity $E_{L}$. In detail, in each additional year, the average output elasticity of capital falls by 0.0075 , but the average output elasticity of labor increases by 0.0062. This result further supports the theory that capital deepening leads to inefficient use of capital (Jun Zhang, 2002).

3) According to efficiency loss estimate model ?, the effects of factors except for price fluctuation on allocation efficiency are presented as follows:

1. Openness has a significant positive spillover effect on allocation efficiency. Allocation efficiency loss as the explained variable, the negative value (4.42) of estimated parameter indicates that a higher degree of openness of a region brings a lower allocation efficiency loss, that is, a higher allocation efficiency. Moreover, the result that openness index is significant at a $1 \%$ level in six regression equations proves that the estimate is robust and that openness has a positive effect on growth. Even without influencing factor input or technological progress, openness still can increase growth of a region by improving the allocation efficiency. 
2. Human capital accumulation has a significant, positive spillover effect on allocation efficiency. The negative value of estimated parameter demonstrates that a region with higher human capital accumulation has higher allocation efficiency on average, which is significant at a $5 \%$ level. Estimates of the other five groups also prove this conclusion.

3. Although models ? and ? indicate that the increase of local government expenditure raises allocation inefficiency, namely, a higher ratio of government expenditure to GDP brings a lower efficiency, the conclusion is not robust, because the parameter estimate is positive but insignificant. This indeterminacy is mainly because of the uncertainty of impacts of government expenditure on allocation efficiency.

\section{CONCLUSIONS}

This paper studies the influence of price fluctuation on resource allocation efficiency from theoretical and empirical perspectives. The theoretical model demonstrates that price fluctuations may cause efficiency loss to enterprises which have adjustment costs. More importantly, in this process a certain pattern can be recognized. Due to the adjustment cost, enterprises may choose to inertly maintain original factor input ratios and production plans confronting small fluctuations. This conservative strategy brings an unavoidable increase in allocation inefficiency caused by price fluctuations. However, greater fluctuations bring a higher opportunity cost to the conservative strategy. As a result, most enterprises adjust their factor inputs to avoid the opportunity cost. The transformation from conservative strategy to adjustment strategy indicates a decreasing trend in the increase of allocation efficiency loss with the augmentation of price fluctuation. Moreover, the total loss of social resource allocation efficiency reaches a limit once price fluctuation exceeds the adjustment cost of each enterprise.

Using SFA with maximum likelihood estimation and China's panel data of 1978 to 2007, this paper calculate the provincial allocation efficiency loss of 
China, and estimate the correlation between price fluctuation and allocation efficiency. Econometric test evidences the main inference that price fluctuations have a nonlinear influence on resource allocation.

This paper has a policy implication that a stable macroeconomic environment is important in obtaining sound resource allocation, not only because the former decrease consumption instability and social welfare loss which are caused by frequent price fluctuations (Lucas, 1987), but also because an unstable environment will lead to resource allocation inefficiency of microenterprises and further reduce TFP as a fundamental factor of growth. The adverse effects of efficiency loss, together with price fluctuation on factor accumulation, may further expand the negative impact of price fluctuation on long term growth ${ }^{5}$.

This paper only focuses on the impacts of price fluctuation on resource allocation efficiency. Since growth of TFP can be delineated into technological progress and resource allocation efficiency, in order to analyze the impacts of price fluctuation on TFP comprehensively, it is also necessary to explore the impacts of price fluctuation on pure technical progress theoretically and empirically. Further research on the impact of price fluctuations on growth will advance this field of study, and inspire producers and policy makers.

\section{References}

Aigner, D. J., Chu, S. F., 1968, On Estimating the Industry Production Function, The American Economic Review, 58(4)

Aizenman, J., Marion, N., 1999, Fluctuation and Investment: Interpreting Evidence from Developing Countries, Economica, (66):157-79.

Aghion, P., Angeletos, G.M., Banerjee, A., Manova, K., 2005, Fluctuation and Growth: Credit Constraints and Productivity-Enhancing Investment, Working paper.

\footnotetext{
${ }^{5}$ Using the provincial panel data of China in 1978-2007, regressing price fluctuation $\Delta \mathrm{P} 2$ with the ratio of fixed assets to China's provincial GDP as capital accumulation index, we obtain I / GDP $=0.3563-0.844 \Delta \mathrm{P} 2$, and t statistics $=70.12$ and $-3.59 . \quad$ This result indicates that price fluctuation and capital accumulation are negatively correlated.
} 
Battese, G.E., Coelli, T.J., 1995, A Model for Technical Inefficiency Effects in a Stochastic Frontier Production Function for Panel Date, Empirical Economics, 5:327-348

Canton, E., 2002, Business cycles in a two-sector model of endogenous growth, Economic Theory, 19 (3): 477-492.

Christensen, L.R., Jorgenson D.W., Lau, L.J., 1973, Transcendental Logarithmic Production Frontiers, The Review of Economics and Statistics, 55(1)

Farrell, M. J., 1957, The Measurement of Productive Efficiency, Journal of the Royal Statistical Society, 120(3)

Fatás, A., Mihov, I., 2006, The Macroeconomic Effects of Fiscal Rules in the US States, Journal of Public Economics, 90(1-2):101-117

Hnatkovska, V., Loayza, N., 2004, Volatility and Growth

Huang, C.J., Liu, J.T., 1994, Estimation of a Non-neutral Stochastic Frontier Production Function, Journal of Productivity Analysis, 4:171-180

Imbs, J., 2007, Growth and fluctuation, Journal of Monetary Economics, (54):1848-1862.

Kose, M. A., Prasad, E.S., Terrones, M. E., 2006, How do trade and financial integration affect the relationship between growth and fluctuation? Journal of International Economics, (69): 176-202.

Kumbhakar, S.C., Ghosh, S., McGuckin, T., 1991, A Generalized Production Frontier Approach for Estimating Determinants of Inefficiency in US Dairy Farms, Journal of Business \&Economic Statistics, 9(3)

Kydland, F. E., Prescott, E.C., 1982, Time to Build and Aggregate Fluctuations, Econometrica, 50(6)

Long, Jr., J. B., Plosser, C.L., 1983 Real Business Cycles, The Journal of Political Economy, 91(1)

Lucas, R. E., 1987, Models of Business-cycles

Mankiw, N.G., 1991, The Reincarnation of Keynesian Economics , Working Paper

Mobarak, A., M. 2005, Democracy, Fluctuation and Development. The Review of Economics and Statistics, 87 (2).

Nelson, C. R., Plosser, C. R., 1982, Trends and Random Walks in Macro- 
econmic Time Series: Some Evidence and Implications, Journal of Monetary Economics, 10(2): 139-162

Pindyck, R.S., 1991, Irreversibility, Uncertainty, and Investment, Journal of Economic Literature, American Economic Association, 29(3): 1110-48.

Ramey, G., Ramey, V., 1995, Cross-country evidence on the link between fluctuation and growth, American Economic Review, (85): 1138-1151.

Rafferty, M., 2004, Growth-business cycle interaction: A look at the OECD, International Advances in Economic Research, 10(3):191-201.

Romer, D., 1996, Advanced Macroeconomics, The Economic Journal, 1(493): 282-289

Turnovsky, S. J., Chattopadhyay, P., 2003, Fluctuation and growth in developing economies: some numerical results and empirical evidence, Journal of International Economics, (59): 267-295.

Wang, H.J., Schmidt, P., 2002, One-Step and Two-Step Estimation of the Effects of Exogenous Variables on Technical Efficiency Levels. Journal of Productivity Analysis, (18): 129-144.

Li, Y.Y., 2006, Impairment effects of Economic Fluctuations on Economic Growth: Evidences from China, Modern Economic Science, (4).

Liu, J.Q., Zhang, H., 2003, Impact Transmission of Economic Growth Risk and 'Spillover Effect' of the Economic Cycle Fluctuations, Economic Research, (10).

Lu, E.P., Wang, Z.T., 2007, The Effects of Economic Fluctuation on Longterm Growth, Statistical Research, (6).

Shan, H.J.,2008, Re-estimation of Capital Stock K in China: 1952-2006, Quantitative \& Technical Economics Research, (10).

Wang, Z.G., Gong, L.T., Chen, Y.Y., 2006, Decomposition of Regional Productivity and Total Factor Productivity Growth (1978-2003), China Social Sciences, (2). 


\section{TJEČAJ FLUKTUACIJE CIJENA NA EFIKASNOST RASPODJELE RESURSA}

Sažetak:

Ovaj rad razvija dinamički model za analizu efekata različitih nivoa fluktuacija cijena na efikasnost raspodjele resursa. Model pokazuje dvije različite strategije koje poduzeća usvajaju pri suočavanju s različitim nivoima fluktuacije cijena. Kao odgovor malim fluktuacijama, poduzeća bi mogla usvojiti konzervativnu strategiju održavanja omjera faktorskih troškova $i$ ostavljanja proizvodnih planova nepromijenjenim za troškove prilagodbe. Na taj način je neefikasnost raspodjele neizbježna. Ipak, véce fluktuacije koje pové́avaju mogućnost troška konzervativne strategije prisiljavaju poduzeća da prihvate strategiju prilagodavanja; moraju pasivno promijeniti omjer faktorskih troškova i planova proizvodnje. Ova transformacija ukazuje na to da postoji efekt praga kod utjecaja fluktuacije cijena na neefikasnost raspodjele resursa. Koristé́i analizu stohastičkih granica (SFA) i kineske provincijske panelne podatke od 1978. do 200\%., ovaj rad potvrduje da fluktuacija cijena ima nelinearni efekt na gubitak efikasnosti raspodjele te zaključuje da tradicionalne analize podcjenjuju negativne utjecaje fluktuacije cijena na kinesku ekonomiju.

Ključne riječi: fluktuacija cijena, efikasnost raspodjele, efekt praga, analiza stohastičkih granica 